\title{
Correction: Antigen-specific T cell Redirectors: a nanoparticle based approach for redirecting $\mathrm{T}$ cells
}

\section{Christian Schütz ${ }^{1,4}$, Juan Carlos Varela ${ }^{2}$, Karlo Perica ${ }^{1}$, Carl Haupt ${ }^{1}$, Mathias Oelke ${ }^{1,3}$ and Jonathan P. Schneck ${ }^{1}$}

\author{
${ }^{1}$ Institute of Cell Engineering and Department of Pathology, Johns Hopkins School of Medicine, Baltimore, Maryland, USA \\ 2 Division of Hematology, Department of Medicine, Sidney Kimmel Comprehensive Cancer Center, The Johns Hopkins \\ Hospital, Baltimore, Maryland, USA \\ ${ }^{3}$ NexImmune Inc., Gaithersburg, Maryland, USA \\ ${ }^{4}$ Current address: Division of Immunology, Paul-Ehrlich-Institut, Langen, Germany \\ Published: August 17, 2018
}

Copyright: Schütz et al. This is an open-access article distributed under the terms of the Creative Commons Attribution License 3.0 (CC BY 3.0), which permits unrestricted use, distribution, and reproduction in any medium, provided the original author and source are credited.

This article has been corrected: The correct funding information is given below:

\section{FUNDING}

This work was in part supported by German Cancer Foundation (Grant no. 70112372), German Research Foundation (SCHU 2681/1-1), HERA Women's Cancer Foundation OSB1 Grant (C.S.) and the National Institutes of Health (P01-AI072677, R01CA108835 and R21-CA185819), TEDCO/Maryland Innovation Initiative and Neximmune, Inc. MD Biotech Center (J.P.S.).

Original article: Oncotarget. 2016; 7:68503-68512. https://doi.org/10.18632/oncotarget.11785 